\title{
Oil spills and sea turtles: documented effects and considerations for response and assessment efforts
}

\author{
Bryan P. Wallace ${ }^{1,2,11, *}$, Brian A. Stacy ${ }^{3}$, Eduardo Cuevas ${ }^{4}$, Carly Holyoake ${ }^{5}$, \\ Paulo H. Lara ${ }^{6}$, Ana Claudia J. Marcondes ${ }^{6}$, Jeffrey D. Miller ${ }^{7}$, Hugo Nijkamp ${ }^{8}$, \\ Nicolas J. Pilcher ${ }^{9}$, Ian Robinson ${ }^{8}$, Nicolle Rutherford ${ }^{10}{ }^{,}$Gary Shigenaka ${ }^{10}$ \\ ${ }^{1}$ Conservation Science Partners, Inc., Truckee, CA 96161, USA \\ ${ }^{2}$ Nicholas School of the Environment, Duke University Marine Lab, Beaufort, NC 28516, USA \\ ${ }^{3}$ Office of Protected Resources, National Oceanic and Atmospheric Administration-National Marine Fisheries Service, \\ Gainesville, FL 32611, USA \\ ${ }^{4}$ CONACYT - Universidad Autónoma del Carmen, Ciudad del Carmen, Campeche 24155, Mexico \\ ${ }^{5}$ School of Veterinary Medicine, Murdoch University, Murdoch, Western Australia, 6150, Australia \\ ${ }^{6}$ Fundação Pro TAMAR, Praia do Forte, Bahia 48280-000, Brazil \\ ${ }^{7}$ Biological Research and Education Consultants, Missoula, MT 59801, USA \\ ${ }^{8}$ Sea Alarm Foundation, 1000 Brussels, Belgium \\ ${ }^{9}$ Marine Research Foundation, 88450 Kota Kinabalu, Sabah, Malaysia \\ ${ }^{10}$ Emergency Response Division, National Oceanic and Atmospheric Administration, Seattle, WA 98115, USA \\ ${ }^{11}$ Present address: Ecolibrium, Inc., 5343 Aztec Drive, Boulder, CO 80303, USA
}

\begin{abstract}
Hydrocarbon (i.e. oil) extraction, transport, consumption, and pollution occur daily in marine environments, threatening vulnerable natural resources, habitats, and biodiversity. However, threats of episodic oil spills to imperiled marine species are not as well-studied as more acute, readily apparent threats such as incidental capture in fisheries and habitat degradation. We performed a global review of spill incident databases to evaluate reported effects of oil spills on sea turtles, which are flagship species of the world's oceans. Our goals were to (1) summarize available information about oil spills and their effects on sea turtles; (2) identify major knowledge gaps; and (3) provide recommendations related to oil spills and sea turtles for managers, researchers, and conservation groups around the world. Over 2000 oil spill incidents of variable magnitude (range: $\sim 20$ to $>1$ million barrels) have occurred worldwide in the past $60 \mathrm{yr}$ in areas where sea turtles are found, but resulting effects on sea turtles have been reported in less than $2 \%$ of those incidents. Further, evidence indicates that most effects are related to heavy external oiling, while chemical effects of oil exposure have not been well defined. We recommend that, where available, resources be prioritized to document co-occurrence of turtles and oil, the degree and nature of oil exposure, and mortality and reproductive losses to individual sea turtles and their populations caused by spills and spill response activities. These data will best inform assessments of the extent and magnitude of adverse effects of oil spills on sea turtles.
\end{abstract}

KEY WORDS: Oil spills $\cdot$ Oil exposure $\cdot$ Spill response $\cdot$ Sea turtles $\cdot$ Deepwater Horizon

${ }^{*}$ Corresponding author: ecolibrium.inc@gmail.com (c) The authors, and outside the USA, the US Government 2020. Open Access under Creative Commons by Attribution Licence. Use, distribution and reproduction are unrestricted. Authors and original publication must be credited. 


\section{INTRODUCTION}

Every day around the world, hydrocarbons (i.e. oil) are sought, extracted, transported, refined, and consumed across land and sea. A large portion of global energy demand is still satisfied by oil (33\%) (Maribus 2014). However, oil is not just an energy source; it is also an important input to pharmaceutical and chemical industries, such as for production of omnipresent plastics (Maribus 2014). Oil spills are an inherent risk associated with extraction and transportation activities and many have had destructive effects on wildlife and the environment (Seymour \& Geyer 1992, Piatt \& Ford 1996, Peterson et al. 2003, DWH NRDA Trustees 2016). Most incidents that occur in marine and coastal areas are related to the location of industry infrastructure and the predominant use of marine transport, the transfer of oil from land-based facilities to tanker vessels, and other types of activities that can lead to spills (Maribus 2014).

The Deepwater Horizon (DWH) spill was an extreme example of the threats posed by oil spills. The DWH spill contaminated $112000 \mathrm{~km}^{2}$ of surface waters and $2100 \mathrm{~km}$ of shoreline (DWH NRDA Trustees 2016). DWH affected a wide diversity of biotic and abiotic natural resources and habitats throughout the Northern Gulf of Mexico ecosystem, including vital foraging, migratory, and breeding habitats of protected marine species such as sea turtles (Wallace et al. 2017a). Upper estimates of sea turtle mortality caused by the DWH spill exceeded 200000 and included multiple species, life stages, and habitats (DWH NRDA Trustees 2016). The DWH spill warranted a comprehensive assessment of environmental damages and eventual settlement between US natural resource trustees and the responsible party, British Petroleum (DWH NRDA Trustees 2016).

The DWH spill was notable because of its magnitude as well as the largely unprecedented effort to comprehensively estimate its effects on sea turtles. This undertaking demonstrated that an oil spill can not only result in large-scale sea turtle mortality, but that mortalities and detrimental effects may go virtually undetected by shore-based observations, where sea turtle monitoring efforts tend to be focused. The challenges of documenting effects on sea turtles in the marine environment are certainly not limited to large spills; the inherent life history traits of sea turtles and their associated movements make it particularly difficult to determine the effects of an oil spill when sea turtles are dispersed at sea (Musick \& Limpus 1997, Plotkin 2003).
It is within this context that we performed a global review of effects of oil spills on sea turtles, which are considered flagship species of the world's oceans (Frazier 2009). Most attention to threats that affect sea turtles has focused on the most acute, readily apparent causes of population-level imperilment: fisheries bycatch, human consumption of sea turtles and their eggs, and coastal development (Wallace et al. 2011). Population-level effects of other potentially significant threats remain largely projected or speculative (e.g. climate change) or relatively understudied (e.g. pollution, disease) (NMFS. USFWS and SEMARNAT 2011, Wallace et al. 2011, Hamman et al. 2013). In response to these data needs, effects of some types of pollution, such as marine debris, have recently received increased attention (e.g. Nelms et al. 2016). However, effects of chemical spills — oil, in particular-remain poorly understood.

The overarching goal for this review was to foster better understanding of the effects of oil spills on sea turtles in order to enhance efforts to document and minimize those effects to the extent possible during future spills. We acknowledge a few important limitations of our review at the outset. First, this review is unavoidably biased toward information from and legal structures governing oil spill response and assessment in developed countries, particularly the USA. This bias results from the preponderance of available data about spill effects on sea turtles having been collected by US natural resource agencies during spills within US and territorial waters under US laws (Stacy et al. 2019). However, we have tried to ensure that the applicability of our findings and recommendations is not significantly restricted by this geographic bias.

Second, we acknowledge that our recommendations will be infeasible in some, perhaps many, circumstances. Rather than limiting our suggested actions to those that are possible in all situations, we based our recommendations on the information required to adequately assess impacts and to minimize the effects of a spill on sea turtles, regardless of available means. Despite the potential gaps between 'optimal' assessment and response approaches and the physical resources available to conduct them, the content, findings, and recommendations of this review are intended to be adaptable and scalable in a variety of circumstances.

Lastly, although large, highly visible oil spills garner considerable attention and concern from the public, natural resource managers, and scientists (Seymour \& Geyer 1992), they account for a small fraction of the number of spills and cumulative volume of 
petroleum products spilled into the world's waterways. The World Ocean Review (Maribus 2014) estimated that as much as $80 \%$ of global marine oil pollution comes from regular shipping operations (e.g. transfer of oil, illegal tank cleaning), municipal and industrial effluents, and routine oil rig operations, and sea turtles are vulnerable to oil from all of these sources (Witherington 2002, Camacho et al. 2013). Though the focus of this review is larger, documented oil spills, potential threats posed by other, more pervasive sources of marine petroleum pollution, as well as natural seeps of oil from the seafloor, are acknowledged.

The objectives of this review were to (1) summarize available information about oil spills and their effects on sea turtles, (2) identify major knowledge gaps, and (3) provide recommendations related to oil spills and sea turtles for managers, researchers, and conservation groups around the world. To accomplish these objectives, we structured the review as follows. First, we briefly summarized traits of the biology and life history of sea turtles that make them vulnerable to oil spills. Next, we reviewed existing data on oil spills and their effects on sea turtles, as well as approaches for documenting, quantifying, and minimizing those effects. Finally, we concluded by identifying key data gaps, priorities, and recommendations to bolster future efforts to plan and implement oil spill response and assessment activities focused on sea turtles. It is worth noting that our focus on sea tur- tles in this review was not intended to diminish the importance of prioritizing human well-being in spills or that of other organisms (e.g. marine mammals, birds). Rather, our intent was to provide a summary of existing information to help inform efforts of governmental and non-governmental wildlife organizations and industry personnel that may be called upon during an oil spill.

\section{HOW BIOLOGY AND LIFE HISTORY MAKE SEA TURTLES SUSCEPTIBLE TO EFFECTS OF OIL SPILLS}

Life history characteristics and sea turtle biology, such as the distribution of different life stages and seasonal movements related to reproduction, foraging, and environmental factors (Miller 1997, Musick \& Limpus 1997, Plotkin 2003), fundamentally influence the scale and nature of spill-related impacts (Lutcavage et al. 1997). The generalized sea turtle life cycle is described in detail elsewhere (e.g. Bolten 2003), but briefly summarized here in the context of oil exposure risk.

Oil spills and efforts undertaken to collect or dispose of spilled oil pose a number of potential threats to sea turtles on land and at sea, depending on where and when a spill occurs, what species and life stages are present, and how turtles use habitats within the spill area (Lutcavage et al. 1997) (Fig. 1). Sea turtle

Terrestrial environment - nesting beaches Females, eggs, hatchlings

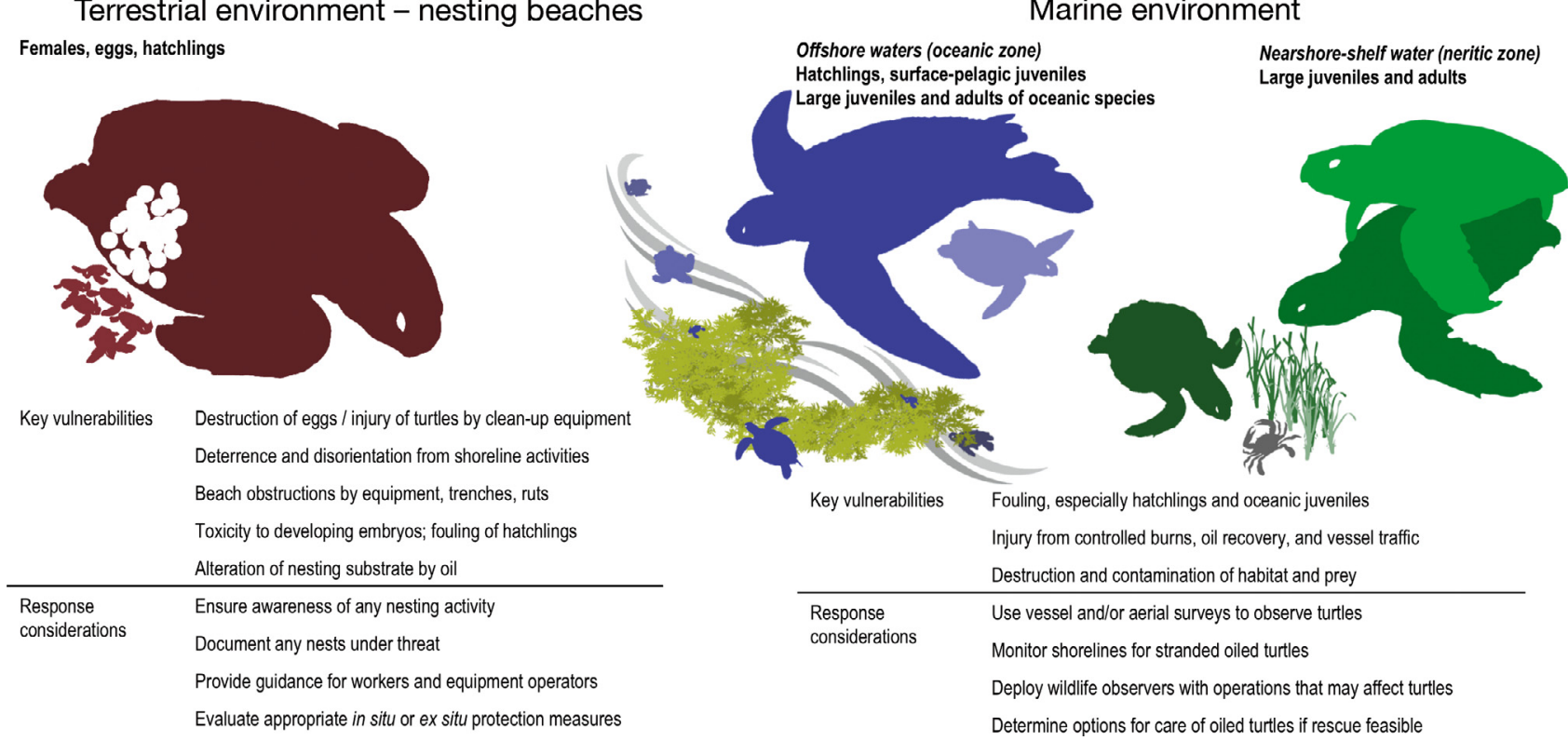

\section{Marine environment}

Fig. 1. Sea turtle life history by generalized life stages. Accompanying text summarizes key vulnerabilities to oil spills and associated response activities, as well as considerations for oil spill response and assessment efforts, by life stage and habitat 


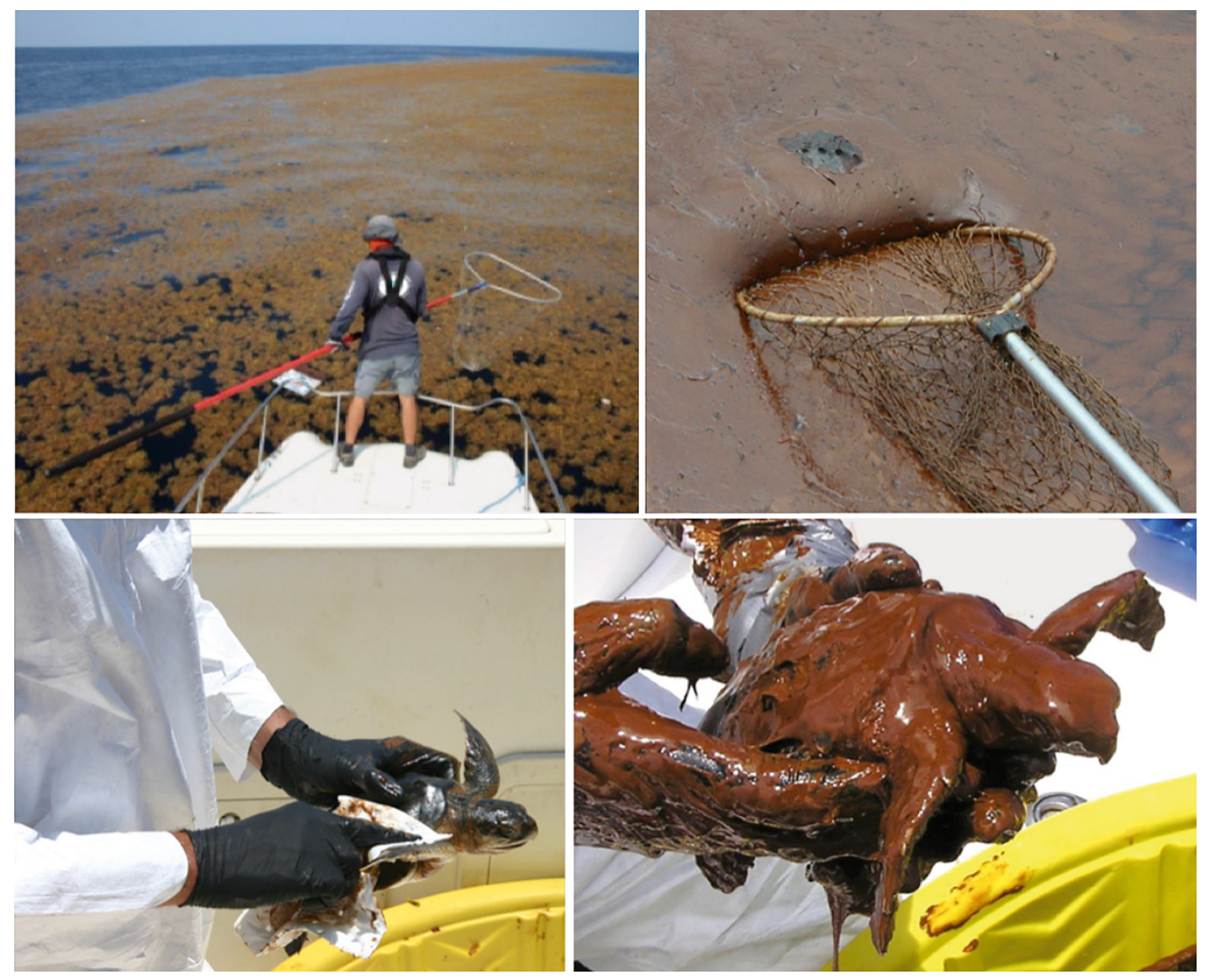

Fig. 2. Clockwise from top left: responders searched convergence areas where oil, Sargassum, and turtles were aggregated during the Deepwater Horizon oil spill. When turtles were observed, responders attempted to rescue them from the surface using dipnets. Oiled turtles were then brought aboard rescue vessels, examined, and cleaned. Turtles were then taken to rehabilitation facilities to receive extended veterinary care until they were ready for release. Photos: NOAA

nesting beaches are especially vulnerable to oil spills because oil tends to be deposited on shorelines by wind and currents where it may impact female turtles, nests and eggs, and hatchlings. In addition, green turtles Chelonia mydas regularly come ashore to bask in areas of the Pacific including Australia and the Hawaiian archipelago (e.g. Whittow \& Balazs 1982). Extending seaward from shore, the neritic zone includes important habitats for juvenile and adult sea turtles (Musick \& Limpus 1997, Bolten 2003) that are often contaminated by oil spills in coastal areas. Sea turtles are found within bays, sounds, estuaries, tidal creeks, and open shelf waters, from the water's surface to the ocean bottom. They forage within many different habitat types, including hard and soft bottom areas, mangrove forests, seagrass beds, various types of reefs, and artificial structures (e.g. rock jetties). The density of sea turtles can be relatively high in productive foraging areas or near nesting beaches during reproduction.
Sea turtles are also at risk from oil spills in offshore areas where turtle distribution and density can be especially dynamic (Musick \& Limpus 1997, Mansfield \& Putman 2013). Of particular concern are hatchlings and small surface-pelagic juveniles, which are extremely vulnerable to oil spills because oil tends to collect within convergence fronts that these animals utilize for developmental habitat (Fig. 1) (Witherington et al. 2012). Their small size limits their ability to avoid or escape surface oil (Fig. 2). Distribution and numbers of surface-pelagic juveniles vary depending on temporal and regional patterns of dispersal, oceanographic conditions, and productivity of nesting beaches (Mansfield \& Putman 2013).

Though this synopsis applies to many sea turtle populations and most species, spill response efforts should be based on location-specific environmental and marine habitat data as well as sea turtle presence, distribution, and habitat use, to the extent that such data are available. 
Table 1. Number of oil spill incidents and estimated volume of oil spilled worldwide (1967-2017), and the number in which sea turtles were either specifically mentioned as 'at risk' of exposure, were assessed for potential effects, or were documented to have been affected ('turtles potentially affected')

\begin{tabular}{|lccccc|}
\hline & $\begin{array}{c}\text { No. of } \\
\text { incidents }\end{array}$ & $\begin{array}{c}\text { No. of incidents in } \\
\text { which vol. of spilled } \\
\text { oil reported }\end{array}$ & $\begin{array}{c}\text { Total vol. } \\
\text { spilled } \\
\text { (barrels) }\end{array}$ & $\begin{array}{c}\text { Avg. vol. } \\
\text { spilled per incident } \\
\text { (barrels) }\end{array}$ & $\begin{array}{c}\text { Incidents } \\
\text { (turtles poten- } \\
\text { tially affected) }\end{array}$ \\
\hline Global & 2316 & 1691 & 56234000 & 33255 & 22 \\
Subtropics $\left(40^{\circ} \mathrm{N}\right.$ to $\left.40^{\circ} \mathrm{S}\right)$ & 1432 & 997 & 37706000 & 37820 & 22 \\
Tropics $\left(23.5^{\circ} \mathrm{N}\right.$ to $23.5^{\circ} \mathrm{S}$ ) & 191 & 133 & 9861000 & 74140 & 9 \\
\hline
\end{tabular}

\section{SUMMARY OF OIL SPILLS WITH IDENTIFIED OR SUSPECTED EFFECTS ON SEA TURTLES}

Although sea turtles are globally distributed, we focused on data from incidents occurring within the primary latitudinal range of sea turtle species (Wallace et al. 2010). Specifically, we focused on spills that occurred within the tropics $\left(23.5^{\circ} \mathrm{N}\right.$ to $\left.23.5^{\circ} \mathrm{S}\right)$, which tend to host core sea turtle distributions (particularly during reproduction), and the subtropics (from the tropics to $40^{\circ} \mathrm{N}$ and $40^{\circ} \mathrm{S}$ ). We characterized all spills within this range regardless of whether sea turtle impacts were documented, but specifically evaluated those in which effects on sea turtles were reported. In addition, we overlaid an extensive global data set of sea turtle nesting sites (The State of the World's Sea Turtles, SWOT; Kot et al. 2015) in ArcGIS 10.2.1 (ESRI) to visualize the degree of overlap between spill incidents and nesting locations.

Our primary resource, particularly for incidents that occurred in US waters, was NOAA's Office of Response and Restoration (ORR) Historical Incidents database (https://catalog.data.gov/dataset/noaas-officeof-response-and-restoration-historical-oil-and-chemical -spill-incidents-database549ad), which contains reports from oil and chemical spills between 1968 and 2017. We augmented this data set with others that focused on spills that occurred outside US waters, including the International Tanker Owners Pollution Federation Limited (ITOPF) oil tanker spill statistics (ITOPF 2017), the World Ocean Review (Maribus 2014), and the Centre of Documentation, Research, and Experimentation on Accidental Water Pollution (CEDRE; http://wwz.cedre.fr/en/). Because reporting became more consistent after 1957, we focused our analyses from this year onward.

Our review found that 2316 spills totaling nearly 56 million barrels occurred worldwide in the past 60 yr (Table 1). The volume spilled per year has fluctuated over time, but has not increased despite an increase in reported spills (Fig. 3). Nearly two-thirds
( $n=1432)$ of these incidents occurred within subtropical latitudes in which sea turtles most frequently occur (i.e. $40^{\circ} \mathrm{N}$ to $40^{\circ} \mathrm{S}$ ) (Fig. 4), averaging 37820 barrels spilled per incident (Table 1). Spills in the tropics averaged 74140 barrels per spill (Table 1) and accounted for less than $10 \%(n=191)$ of all incidents. Relatively few spills have been reported from several global regions, mainly in the Southern Hemisphere (Figs. 4 \& 5). This disparity likely reflects higher levels of production, transport, and risk of oil spills occurring in North America, Europe, and the Middle East, as well as the geographic bias of our data sources.

Despite the global extent of spills, impacts on sea turtles were reported in only $1.5 \%$ of spills (22 of 1432) that occurred with $40^{\circ}$ latitude of the equator (i.e. the general distribution of sea turtles) and $4.7 \%$ of spills (9 of 191) within the tropics (Table 1, Figs. 4 $\& 5)$. Of the 22 spills where sea turtle impacts were documented, 13 occurred in North America (USA, Mexico, Central America, and the Caribbean), 1 in the Western Pacific (Guam), 2 in South America, 3 in the Middle East, and 3 in Australia (Fig. 5). These spills ranged in size from $\sim 20$ barrels (e.g. 'Shen Neng 1', Great Barrier Reef, Australia) to $>1$ million barrels (e.g. Ixtoc 1, Bay of Campeche, Mexico; DWH, Gulf of Mexico; the Gulf War, Persian Gulf) (Fig. 5).

Reported effects of oil spills on sea turtles tended to be opportunistic observations (Table 2), and numbers of turtles affected, when reported, were typically small because rigorous quantification has been very rare (Table 2). In the 1991 Gulf War spill in the Persian Gulf - the largest oil spill involving reported effects on sea turtles ( $>5.71$ million barrels spilled) only 5 dead turtles were documented, and only 10s100s were estimated to have been killed (Table 2). Oil spill effects on shore involving nesting females, eggs, and hatchlings have been reported more frequently than effects on turtles in the water (Table 2), though specific life stages have not always been 


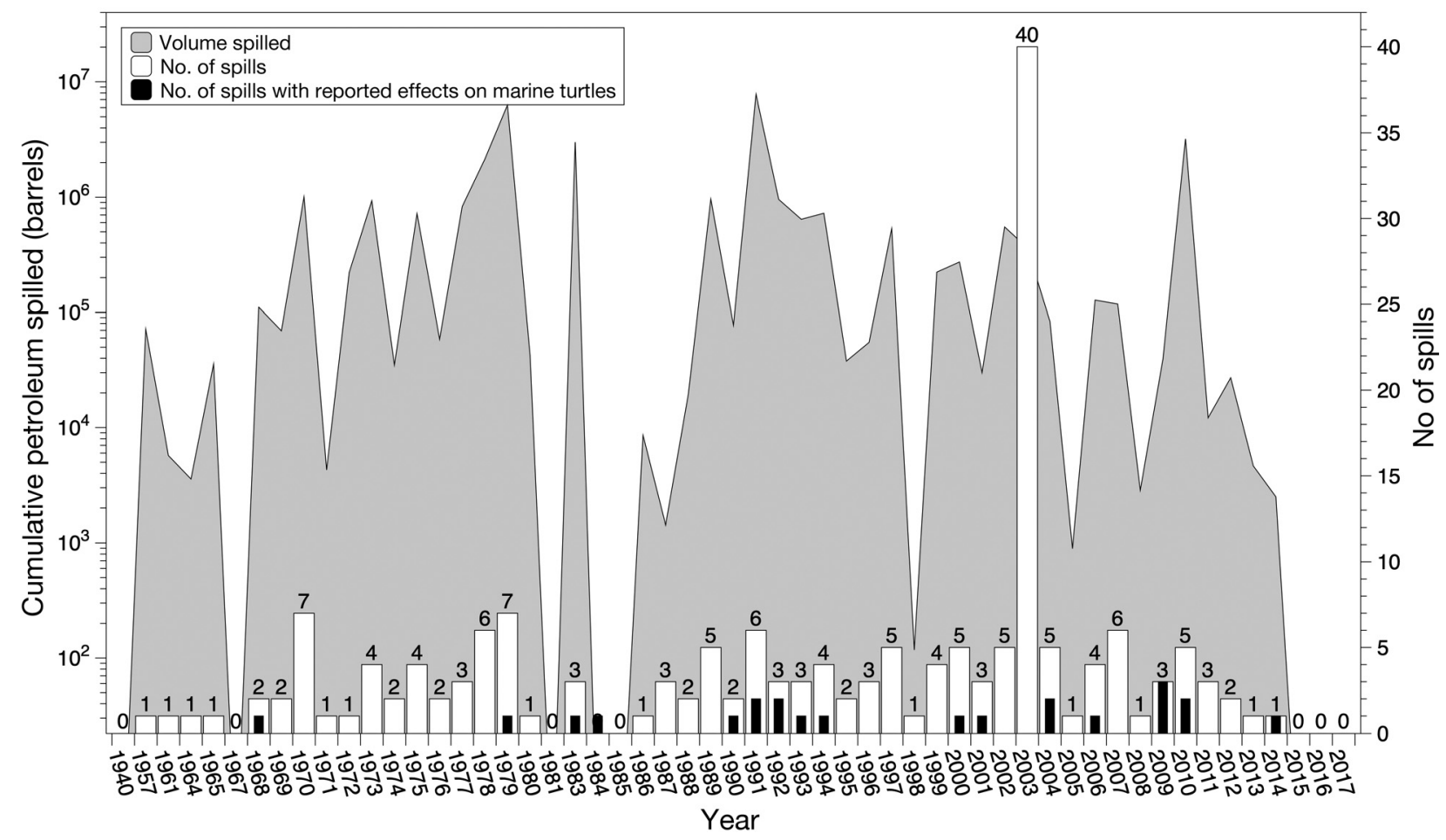

Fig. 3. Number and estimated volume of reported oil spills worldwide from 1940-2017. Numbers atop white columns: number of spills; black bars: number of spills in which potential effects on sea turtles were noted (total = 22 incidents)

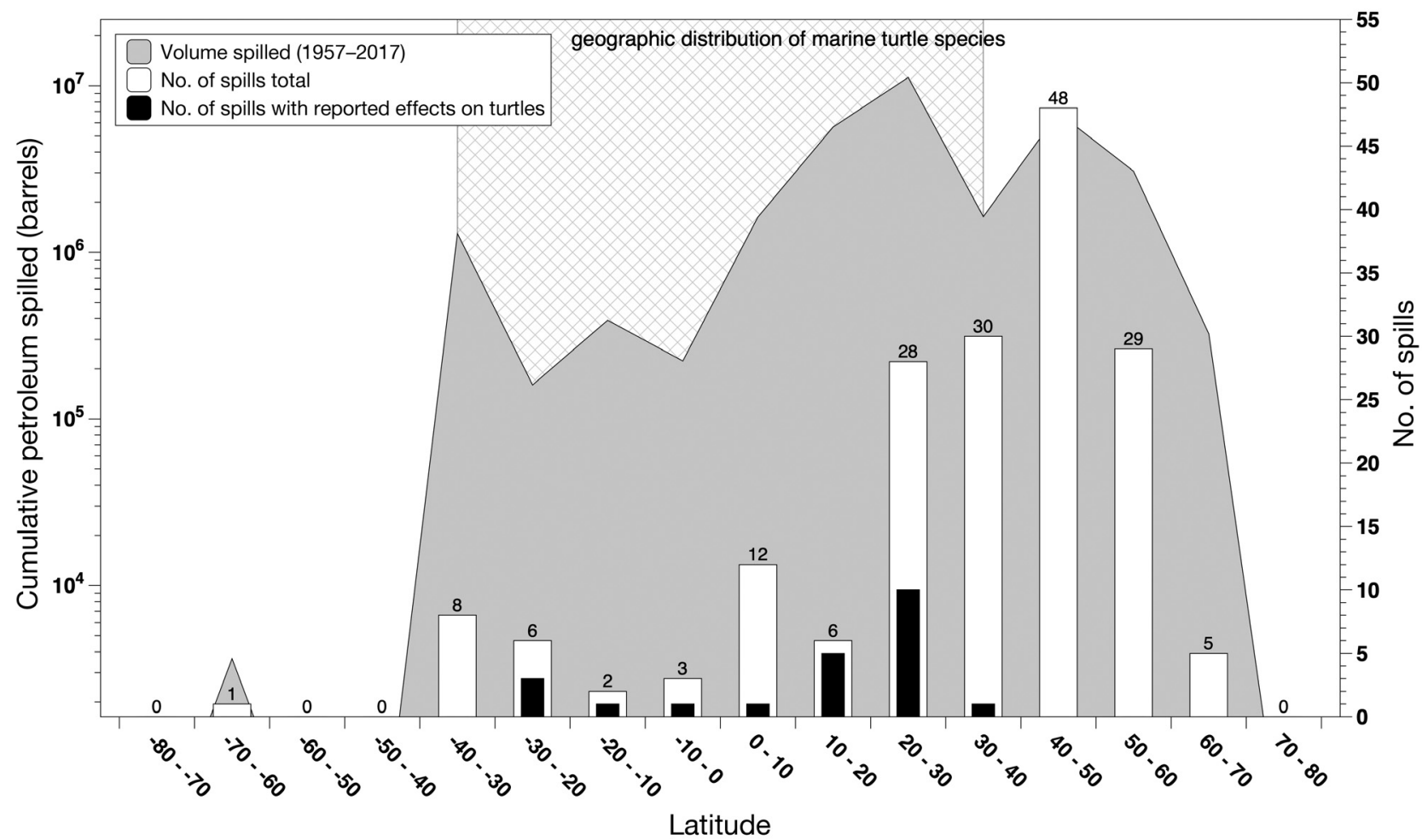

Fig. 4. Number and estimated volume of reported oil spills shown by latitude from 1957-2017. Numbers atop white columns: number of spills; black bars: number of spills in which potential effects on sea turtles were noted (total = 22 incidents, maximum $=11$ between 20 and $30^{\circ} \mathrm{N}$ latitude) 


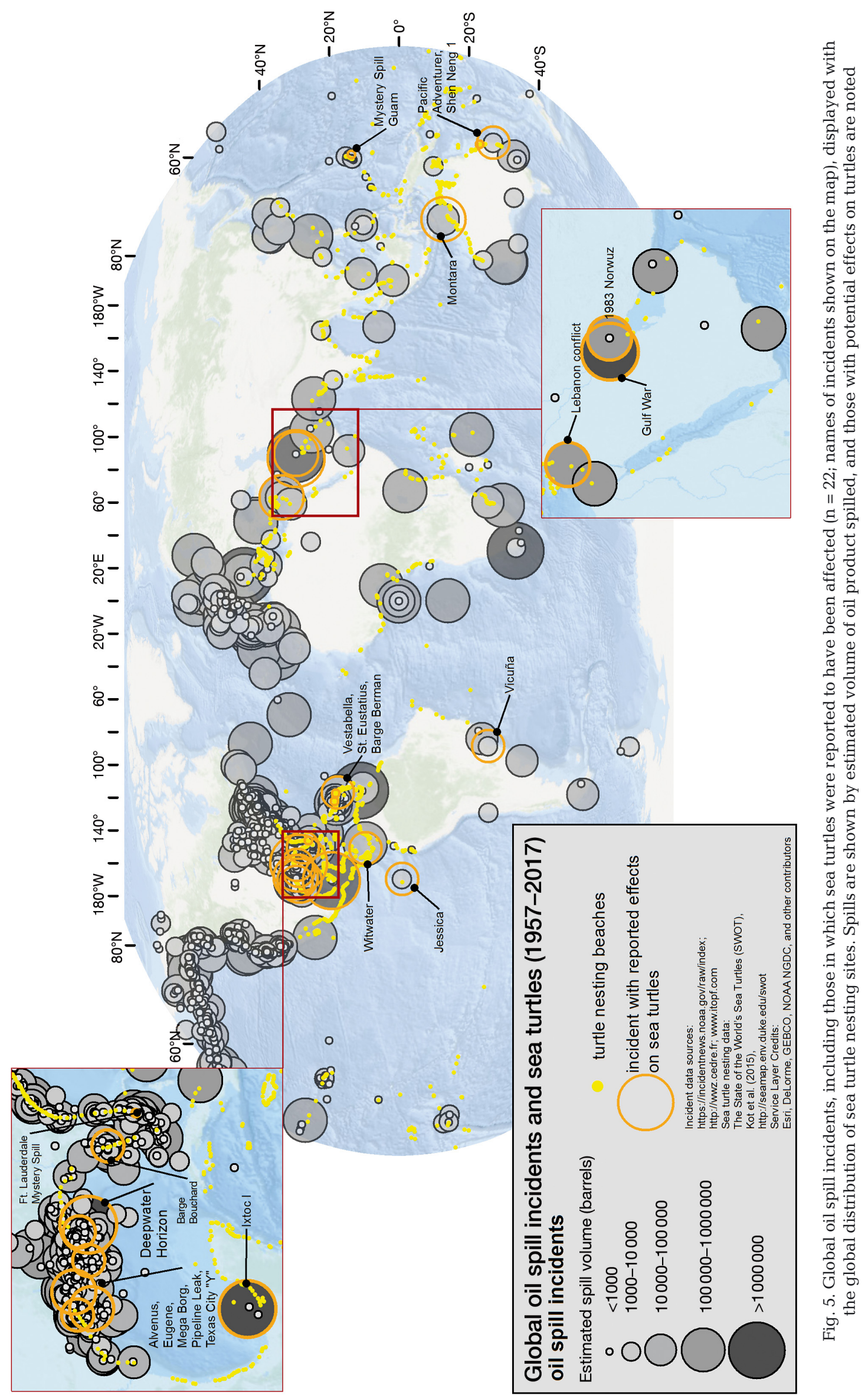


(1)

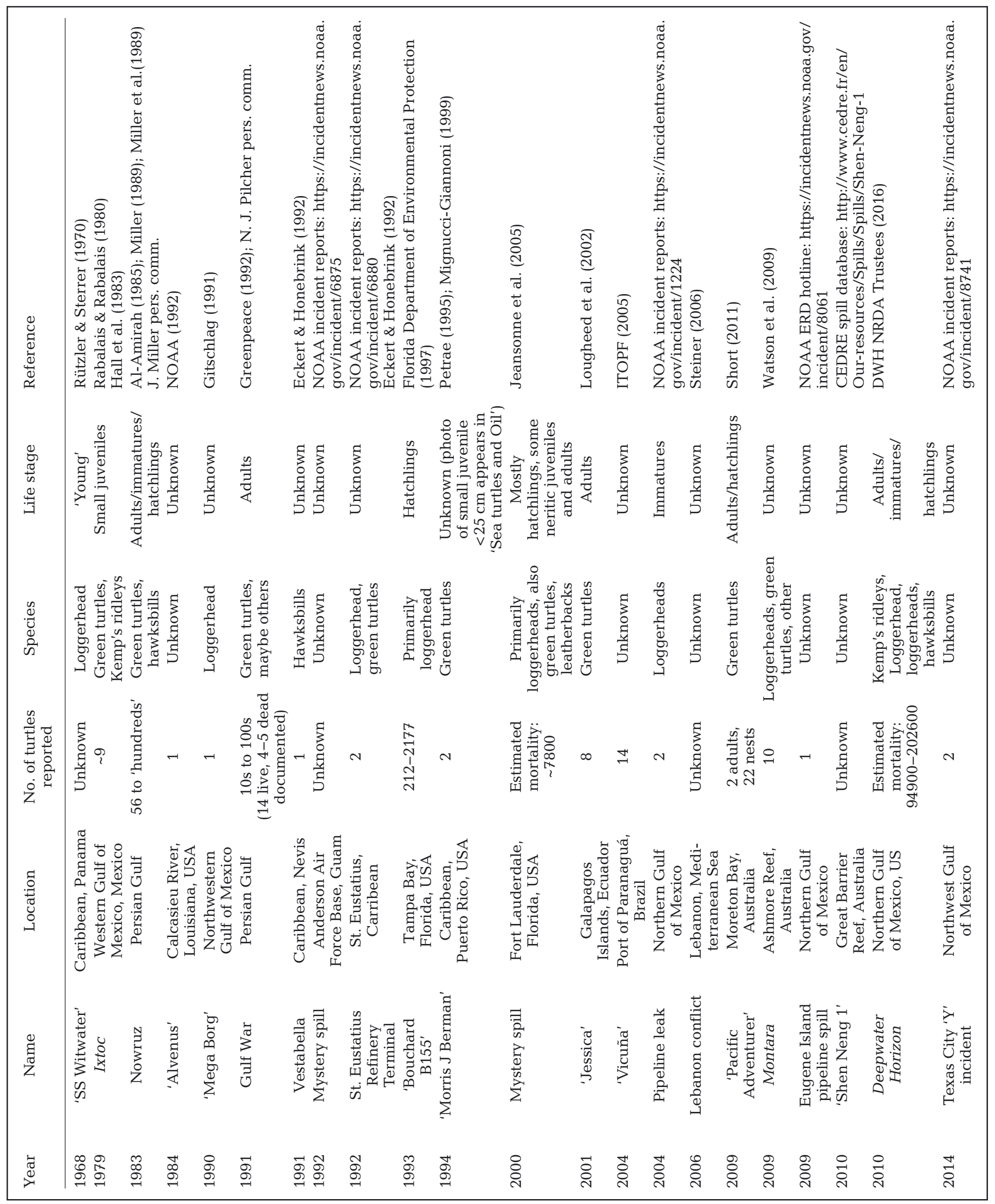


reported. These omissions limit our understanding of the vulnerabilities of some life stages based on prior spills.

Our review demonstrates that effects of oil spills on sea turtles are rarely reported, despite the prevalence of incidents in areas where sea turtles are known to be present, breed and nest, forage, and migrate. This discrepancy is unsurprising given that, even under normal, non-spill conditions, turtles are highly mobile, ocean-going animals that are often relatively difficult to observe, study, and monitor, especially in remote areas (Bolten 2003, Plotkin 2003).

\section{REVIEW OF DOCUMENTED EFFECTS OF OIL SPILLS ON TURTLES}

With the significant exceptions of DWH and the 1991 Gulf War spill, and some limited assessment activities during (e.g. 'Mega Borg'; Gitschlag 1991) or after other spills (e.g. Montara; Watson et al. 2009), there have been very few dedicated efforts to systematically observe and record the condition of sea turtles during oil spills in marine and terrestrial areas, or to assess the adverse effects caused by an oil spill or containment and clean-up response actions. Opportunistic observations are the rule rather than the exception for descriptions of oil spill impacts on sea turtles; most incident reports merely mention that sea turtles were observed, without providing numbers or life stages (or sizes) of animals, species, or details about their condition (Table 2).

The exceptions to these opportunistic observations were cases in which sea turtle 'injuries' (i.e. observed or measured adverse effects, including mortality, caused by oil spills) were assessed formally through Natural Resource Damage Assessments under the US Oil Pollution Act of 1990 (OPA; 15 CFR § 990.30). Natural resource trustees (i.e. state and federal government agencies, tribal entities, or others with legal jurisdiction) attempted to quantify injuries caused by these incidents (Florida Department of Environmental Protection 1997, 2002, Jeansonne et al. 2005, DWH NRDA Trustees 2016) (Table 2). Injury quantification in 2 of these cases ('Bouchard' and the mystery spills) focused almost solely on effects on eggs and hatchlings on or near nesting beaches, with virtually no estimates of effects on older life stages (Florida Department of Environmental Protection 2002, Jeansonne et al. 2005). In contrast, between 100000 and 200000 turtles, mostly surface-pelagic juveniles, were estimated to have been killed during the DWH spill (DWH NRDA Trustees 2016, McDonald et al. 2017). DWH was the first and only oil spill for which a comprehensive estimate of effects was determined for different sea turtle life stages encompassing the entire footprint and duration of the spill area.

Based on information obtained from these spills and related studies (e.g. Vargo et al. 1986, Lutcavage et al. 1995), sea turtles are exposed to petroleum through contact with their skin or eggs, and by ingestion and inhalation. The effects of such exposure generally fall into 2 sometimes interrelated categories: physical effects and chemical or toxicological effects. In addition, spill response actions to contain, recover, disperse, or dispose of spilled petroleum can also adversely affect sea turtles. Potential indirect effects of oil spills on sea turtles through impacted habitat or prey are beyond the scope of this review, but nonetheless are additional important considerations (Fig. 1). In addition, we only briefly mention chemical dispersants in this review because there has been very limited study of their effects on sea turtles.

\subsection{Physical effects of oil on sea turtles}

Physical fouling by oil is the most frequently reported effect of oil exposure on sea turtles (Witham 1978, Florida Department of Environmental Protection 1997, Witherington 2002, Witherington et al. 2012, DWH NRDA Trustees 2016, McDonald et al. 2017). Miring in oil can severely hinder movement, leading to physiological problems, exposure to harsh environmental conditions (e.g. extreme temperatures), vulnerability to predators, and asphyxiation. Tar balls and other thick, tenacious forms of oil can also obstruct the mouth or digestive tract, reducing foraging ability (Witham 1978, Witherington et al. 2012). These effects are most acute and severe for hatchlings and surface-pelagic juveniles because of their small size and dependence on surface habitats where oil accumulates. Heavy fouling in oil was the most readily apparent and immediate harmful effect of the DWH spill on sea turtles (Stacy 2012, DWH NRDA Trustees 2016, McDonald et al. 2017). Veterinarians and biologists determined that heavily oiled turtles rescued during at-sea rescue operations were unlikely to have survived without intervention (DWH NRDA Trustees 2016).

There are similar concerns regarding the physical effects of oil on larger sea turtles, but observations are much more limited (Stacy 2012, DWH NRDA Trustees 2016) (Table 2). In injury assessments of 
multiple spills, observed effects on small juveniles were extrapolated to larger turtles that were not directly observed but were determined via aerial and vessel surveys or satellite telemetry to have been present within the spill area (Florida Department of Environmental Protection 1997, 2002, DWH NRDA Trustees 2016, Wallace et al. 2017b). Crude oil was implicated in the strandings of 14 live adult-sized green turtles in the Persian Gulf in 1991, along with 5 dead turtles (Table 2 ; N. Pilcher pers. obs.). Although not attributed to specific oil spills, occasional strandings of oiled sea turtles have occurred in the Canary Islands (Spain) (Camacho et al. 2013). It is not known to what degree the condition of these turtles was caused by physical effects, toxicity, or a combination of factors.

During the DWH spill, very few oiled neritic juvenile and adult turtles were observed, and only one heavily oiled turtle was encountered that was suspected to have been debilitated by the oil; this was in contrast to the hundreds of observed surface-pelagic juveniles oiled during that incident (Stacy 2012) (Table 2). Compared to surface-pelagic juveniles, larger sea turtles spend less time at the surface, actively transit greater distances underwater between breaths, and may be more physically capable of overcoming restrictions in movement created by fouling (DWH NRDA Trustees 2016). Thus, larger turtles are likely to be less susceptible than small life stages to the physical effects of oil.

Alteration of the physical characteristics of nesting substrate by oil can impact the incubation environment, as well as the respiratory function of eggshells (Phillott \& Parmenter 2001), but requires further study. Effects of shoreline oil deposition can be shortlived or long-term, depending on factors such as degree of inundation, remediation, and entrainment of oil in beach substrate (Peterson et al. 2003). Also, some nesting areas have rocky intertidal platforms that are traversed by hatchlings crawling to the sea, and oil that becomes permanently affixed to rocks can be a persistent hazard (N. Pilcher pers. obs.).

\subsection{Chemical or toxicological effects of oil on sea turtles}

Adverse chemical effects attributed to oil have been extensively reported in a variety of wildlife taxa (e.g. birds: Leighton 1993, Piatt \& Ford 1996; reptiles: Wikelski et al. 2002; marine mammals: Schwacke et al. 2014; fish: Beyer et al. 2016; multiple species: Peterson et al. 2003, Munilla et al. 2011, DWH NRDA
Trustees 2016). Petroleum and related compounds include various complex mixtures of chemicals; toxicological effects of polycyclic aromatic hydrocarbons (PAHs) are the most well-studied. However, the chemical effects of oil exposure on sea turtles have not been demonstrated as frequently or as clearly as the physical effects (Vargo et al. 1986, Shigenaka 2003, DWH NRDA Trustees 2016, Mitchelmore et al. 2017). A recent review of toxicological effects of chemical contaminants on marine turtles supports this assessment; Finlayson et al. (2016, p. 114) excluded studies involving crude oil because 'these have largely focused on physical effects, such as smothering'. Similarly, very few turtle studies have considered the effects of dispersants, which have been shown to affect the bioavailability of PAHs to some organisms (e.g. invertebrates, larval fish) (NRC 2005, DWH NRDA Trustees 2016). This is another important information gap.

The current understanding of toxicological effects of oil on sea turtles has been derived from a small number of empirical studies and controlled experiments, restricted by the protected status of sea turtle species (for reviews see Shigenaka 2003 and Mitchelmore et al. 2017). Although these barriers do not exist for the study of non-imperiled chelonians as surrogates, few such studies exist (Bell et al. 2006, Rowe et al. 2009, Van Meter et al. 2006). Given the general paucity of available information, we reviewed reports of both natural and experimental exposures of any species of chelonians to crude oil and other types of petroleum.

Studies of petroleum toxicity in turtles under natural and laboratory settings have yielded mixed results. The first studies exposed juvenile loggerheads Caretta caretta to crude oil for $2 \mathrm{wk}$ and reported skin lesions, decreased salt gland function, and alteration of some blood cell parameters (Vargo et al. 1986, Lutcavage et al. 1995). Camacho et al. (2013) described various clinicopathological and histopathological abnormalities in stranded juvenile loggerhead turtles (straight carapace length of 13.0$85.2 \mathrm{~cm}$ ) that were oiled by undefined sources, but it was not clear to what degree petroleum actually caused or contributed to the described abnormalities. A laboratory study exposed loggerhead hatchlings (in water) to Gulf Coast mixed sweet crude oil with and without dispersant for 1-4 d and demonstrated their failure to gain weight as a result of both exposures, which was consistent with decreased seawater consumption and dehydration (Harms et al. 2014).

In contrast, many of these effects were not observed in loggerhead and Kemp's ridley Lepidoche- 
lys kempii sea turtles exposed to crude oil during the DWH spill (Stacy 2012, Stacy et al. 2017). Oiled turtles from this spill had nonspecific blood abnormalities including metabolic and physiological derangements consistent with stress, dehydration, and exertion attributable to oiling, capture, and transport, the relative contributions of which could not be discerned (Stacy et al. 2017). No evidence of specific tissue toxicity, hemolytic anemia, or salt gland dysfunction was observed based on histology and blood analyses (Stacy 2012, Stacy et al. 2017). Similarly, red-eared sliders Trachemys scripta elegans and common snapping turtles Chelydra serpentina orally exposed to weathered MC252 (DWH) crude oil daily for $14 \mathrm{~d}$ did not show severe, life-threatening physiological abnormalities, and none died from this exposure (Mitchelmore \& Rowe 2015).

Field and laboratory studies of the effects of oil exposure on turtle eggs likewise have yielded mixed results, ranging from no biological effect to increased deformity rates and mortality (Fritts \& McGehee 1982, Bell et al. 2006, Van Meter et al. 2006, Rowe et al. 2009). Studies of oil exposure on snapping turtle Chelydra serpentina eggs showed decreased hatching success and increased frequency of developmental deformities (Bell et al. 2006, Van Meter et al. 2006). In contrast, another study that exposed artificial nests containing snapping turtle eggs to surface oiling with and without dispersant measured no biological effect, noting that percolation of product through the nest substrate altered the chemical nature of the oil (Rowe et al. 2009). In the only published study of oil effects on sea turtle eggs, nonweathered oil was shown to be more toxic to embryos than weathered oil, suggesting that adverse effects are dependent on the degree of weathering, among other variables (Fritts \& McGehee 1982). Thus, similar to the effects on other life stages, a number of factors, such as the composition of the petroleum, (e.g. type of product, degree of weathering), nesting substrate, environmental conditions, and timing of exposure are likely to influence how oil affects developing sea turtle embryos.

Variation in observed toxicological effects among reports could reflect several factors, such as dose and duration of exposure, characteristics of specific petroleum products (Seymour \& Geyer 1992), potential confounding health problems (e.g. dehydration, poor nutritional condition in stranded turtles), and the non-specific nature of many of the reported observations (Stacy et al. 2019). In addition, methodological differences in some studies are a complicating factor in understanding the effects of oil contamination. For example, Stacy et al. (2017) noted potential concerns related to some of the effects reported in the early loggerhead oil exposure study by Lutcavage et al. (1995), particularly the use of an anticoagulant that may cause hemolysis in reptilian blood and lack of corroborative data to indicate salt gland dysfunction.

One consistent observation is that live turtles that are cleaned of oil and given medical treatment have high probabilities of release back into the wild (Florida Department of Environmental Protection 1997, Camacho et al. 2012, Stacy et al. 2017). However, there are few data on the long-term survival of treated, oiled turtles post-release. Pilcher (2000) reported that several oiled adult turtles treated during the 1991 Gulf War spill went on to nest later that year on the Gulf Islands. Nonetheless, despite some apparent successes with rehabilitation efforts, it is important to remember that the vast majority of sea turtles exposed to an oil spill do not benefit from human intervention (Stacy 2012, McDonald et al. 2017).

\subsection{Effects of spill response activities on sea turtles}

In addition to effects of oil exposure, various actions taken to contain and clean up spills pose significant risks to sea turtles. These threats include heavy equipment, vessels, chemicals (e.g. dispersants), as well as other clean-up devices and techniques used to collect and dispose of oil. On sand beaches, response activities are associated with increased artificial lighting at night, increased human presence, and mechanized clean-up operations to physically remove contaminated sand and debris (Michel et al. 2015). These activities can crush eggs, disorient hatchlings, disturb or deter adult females from nesting, and create obstacles that prevent or hinder access to the beach or sea (Florida Department of Environmental Protection 1997, 2002, Lauritsen et al. 2017).

Offshore spills require activities that are most likely to affect turtles at the surface, particularly small juvenile turtles that dwell in the upper water column (Fig. 1). In marine environments, oil removal via skimming or burning can incidentally entrap and kill sea turtles at the surface or entrained in oil (Florida Department of Environmental Protection 1997, 2002, DWH NRDA Trustees 2016). Increased vessel traffic related to spill response activities can result in greater threat of turtles being struck and killed by watercraft (Stacy 2012, 2015, DWH NRDA Trustees 2016).

Response measures undertaken to directly protect sea turtles can also have uncertain or negative conse- 
quences. For example, sea turtles have been protected from oil by translocating and artificially incubating eggs (i.e. ex situ protection) and relocating individuals (Ixtoc: Shigenaka 2003; DWH: Provancha \& Mukherjee 2011). Such activities avoid immediate threats from a spill and can be a useful - if not the only - option in some circumstances. However, postrelease and long-term survivorship, natal homing (i.e. hatchlings returning to nest on the beaches where they were born), and natural ontogenetic transitions may be adversely impacted (DWH NRDA Trustees 2016).

\section{OIL SPILL RESPONSE AND ASSESSMENT FRAMEWORKS}

Depending on the country, its laws and regulations related to oil spills, and available resources (e.g. trained personnel, equipment, facilities), those responding to wildlife needs during an oil spill might include employees of government agencies, industry, non-governmental organizations (NGOs), academia, or some combination of these entities. Various sources of important expertise (such as specialized knowledge of sea turtles) and critical support infrastructure (such as facilities used for rehabilitation) often require broad cooperation among organizations.

Many countries have laws, regulations, and other instruments that, if enforced, guide oil spill response and provide potential legal and financial responsibilities associated with any damages resulting from a spill. Given the conservation status of sea turtles, some measures (e.g. prohibitions against harassment or injury) may be included in general protected species legislation (see Section 5.1 and 5.2). Others are more specific to oil spills and provide requirements for spill response planning, define key roles to specific groups that may participate in a response, outline frameworks for assessing oil spill effects, and designate requirements for financial support of such efforts and compensation for damages caused by a spill (e.g. the OPA in the USA). Herein, we review examples that are germane to oil spill response planning and execution, and mechanisms of compensation for adverse effects.

\subsection{Oil spill response}

For any wildlife taxon, in order for oil spill response to be most effective, species of concern must be explicitly integrated into broader response efforts, and personnel with taxonomic expertise must be engaged to ensure that specific species concerns are taken into account. Many countries, especially those with an oil production industry, have National Oil Spill Contingency Plans (NOSCPs). The International Petroleum Industry Environmental Conservation Association-International Association of Oil and Gas Producers (IPIECA-IOGP) provides practical guidance on creation of NOSCPs (IPIECA-IOGP 2014).

In the USA, implementation of OPA designates specific roles for government agencies in the natural resource damage assessment (NRDA) framework, and includes development of national, regional, and area spill contingency plans. Important sea turtle information such as seasonal patterns of presence and abundance by species and region, vulnerabilities of sea turtles to oil spills, and response effects by habitat and life stage has been compiled for planning and execution of spill response within US and territorial waters (see Stacy et al. 2019 for an extensive description of the NRDA oil spill response and assessment framework).

Australia's National Plan for Maritime Environmental Emergencies (managed by the Australian Maritime Safety Authority on behalf of the Federal, State and Northern Territory governments and the petroleum and shipping industries) coordinates multisectorial responses to oil spills. The National Plan places responsibility on the State/Territory to develop and implement wildlife response contingency plans (e.g. Marshall \& Bucklow 2014). Petroleum titleholders for each activity are also required to have a government-assessed Oil Pollution Emergency Plan in place, which is consistent with the National Plan and includes oiled wildlife response.

In Mexico, the National Plan of Contingencies for Spills of Hydrocarbons and other Substances Potentially Dangerous for Mexican Marine Zones (SEMARNAT 2016), implemented by the Navy, specifies all the administrative, lobbying, planning, and logistics for attending chemical spills. It also establishes command levels, and includes specifications and procedures for responding to the emergency in terms of human and environmental needs, as well as specifications for financial planning during response and assessment, compensation, and claim processes. For example, this plan includes Local Organisms of Coordination for contingencies operating in each coastal state in Mexico that bring together federal, state, and municipal authorities, security entities (e.g. Army, Navy, Federal Police), federal and state Ministries of Health and Civil Protection, academics, and NGOs. Also, specific guides have been developed for the Net 
Environmental Benefit Analysis for evaluating costs, risks, and the best strategies to manage the spill and repair any negative impacts (SEMARNAT 2012).

Brazilian federal legislation instituted an Information System for Oil Pollution Incident, Emergency Plans, and a National Contingency Plan, and established temporary restriction periods for oil exploration (seismic testing and drilling) in the main sea turtle reproduction areas. In 2017, the Brazilian government published a licensing guide (Sforza et al. 2017), which contains guidelines for the creation of specific measures and conservation actions for marine turtles for coastal and marine enterprises, specifically including oil and gas export and research ventures. Further, as a condition of licensing oil production activities, the Brazilian Institute for the Environment and Renewable Natural Resources defined a Beach Monitoring Program (BMP), which aims to identify any chronic effects of oil activities on marine turtles, birds, and mammals by collecting all strandings possible and identifying the cause of death or rehabilitating live animals. Currently, there are 5 oil industry-related BMPs in Brazil, which monitor $2800 \mathrm{~km}$ of beaches following the same protocols. In addition, Brazil regularly monitors areas off its coast that are at high risk for oil spills. This baseline monitoring enhances response capabilities, facilitates analyses of oil spill effects, and informs priority strategies to mitigate effects of spills and other major threats (Marcondes 2015).

Another resource for spill response planning is a set of country profiles maintained by the ITOPF (https:// www.itopf.org/knowledge-resources/countries-terri tories-regions/), which includes virtually all countries with a coastline. Each profile provides essential information for industry in the event of a spill. In addition, in response to industry's increased requirement for information that enables integration of wildlife into spill response plans, Sea Alarm, a Brussels-based NGO working on preparedness and response to wildlife in oil spills, has produced 'country wildlife profiles' (https://www.sea-alarm.org/publications/countrywildlife-response-profiles/) that include essential information on governmental, academic, and NGO resources specifically related to wildlife, along with details of vulnerable species and habitats. This database demonstrates that oiled wildlife response preparedness in many countries is underdeveloped or absent. Opportunities to proactively protect sea turtles and their habitats, or mitigate the effects of their oiling in the immediate aftermath of an oil spill incident, are easily missed due to lack of knowledge and identified resources.

\subsection{Assessment of effects and remediation}

When assessing effects of an oil spill, characterizing mortality, reproduction losses, and other consequences is critical to determining (and defending) the magnitude of losses and to estimating appropriate compensation for those losses. Opportunistic documentation of the presence of sea turtles and possible adverse effects during spills are generally insufficient for the kinds of robust estimates of overall losses that are required for commensurate compensation. We recognize that intensive effort focused on sea turtles in response to an oil spill, guided by well-designed protocols and executed by specialists, is a best-case scenario that requires dedicated resources that are not universally available. Nonetheless, such measures are warranted to the degree practicable.

Some countries have specific laws that guide information-gathering and analyses to document spill effects on natural resources, including sea turtles, as well as also provide mechanisms to acquire compensation from parties responsible for spills to restore or remediate environmental harm caused by spill incidents. Examples include legal frameworks such as the USA's OPA, Australia's Offshore Petroleum and Greenhouse Gas Storage Act of 2006, and the Mexican Federal Law of the National Agency for Industrial Security and Environmental Protection of the Hydrocarbons Sector 2014. In addition, oil spills from ships are covered by a range of international conventions that provide uniform rules and criteria for compensation in countries that are signatories to relevant conventions when a spill occurs in their territorial waters. However, this compensation may not cover longer term monitoring of the effects of the oil spill on susceptible wildlife species and remediation activities.

Where such legal management frameworks do not exist, other mechanisms might be available to obtain compensation for natural resource restoration. For example, petroleum exploration and extraction operations often rely on funding and insurance from international bodies (e.g. World Bank, Asian Development Bank). These agreements often depend on compliance with environmental regulations and standards, such as the International Finance Corporation's Policy on Environmental and Social Sustainability, which could be a source of leverage for restoration and remediation funds in the event of a spill in the absence of specific national legislation. IPIECA-IOGP (2015) is a useful guide to liability and mechanisms for compensation. 


\section{OIL SPILL RESPONSE AND ASSESSMENT OF EFFECTS ON SEA TURTLES}

Oil spills are emergencies requiring expedited actions to stop the spill, minimize damage to humans, property, and the environment, and to remove contamination. Wildlife response operations during spills tend to be limited in scale, which, in turn, can constrain the information generated for ultimate assessment of damages attributed to a spill. Therefore, we lack a robust global suite of case studies from which to extract and highlight proven strategies and practices (Table 2). However, as demonstrated during the DWH spill, if sea turtles and other wildlife are included as priority natural resources from the beginning of a spill, incident responders can collect valuable information necessary to document and understand the effects of oil spills on these species (Stacy et al. 2019).

Actions taken on behalf of sea turtles may include closely intertwined efforts to (1) minimize the extent of harm and (2) document and assess the degree and nature of resulting negative effects. For example, rescue of live, oiled turtles for decontamination and treatment may save individual animals, but also document effects that can ultimately be used to assess broader impacts on sea turtles, including those that are not rescued (McDonald et al. 2017). In circumstances where capabilities for intervention are limited or infeasible, documentation and assessment of sea turtle impacts is nonetheless important, as it may have implications for management of a particular species or population, or can have bearing on financial or other material restitution that may be used to restore sea turtle losses.

To minimize the effects through intervention, the principle of 'do no harm' should guide efforts to document and rescue sea turtles during oil spills. This applies not only to field-based interventions to rescue oiled turtles, but especially when sea turtles or their eggs are brought into captivity. Before such actions are undertaken, appropriate training, adequate infrastructure, and suitable protocols are required, often with the engagement of necessary experts, to ensure a positive outcome and avoid unintended consequences.

The different life stages of sea turtles and their associated habitats have key characteristics that must be considered when responding to an oil spill and assessing its effects. Because available regional knowledge of sea turtle presence, seasonal movements, and habitats is fundamental to planning and executing a spill response, coordination and communication between spill responders and those with sea turtle expertise is paramount. Spill response teams usually include experts in fields such as oceanographic modeling and meteorology, which can provide valuable real-time information pertinent to anticipated threats to sea turtles and allocation of resources as a spill unfolds. Some adverse effects of oil and response activities on sea turtles are quite obvious, but others require specific expertise and targeted study (Stacy 2012, Stacy et al. 2019). The latter may include thorough veterinary evaluation of live turtles, postmortem examinations (necropsy) of dead turtles, and analysis of broader effects, such as those on specific demographics, habitat, or prey. The following sections present options for response and assessment of spill effects for 3 principal ecological zones utilized by sea turtles, as applied in this review.

\subsection{Nesting beach (terrestrial) zone}

When a spill occurs within an area and period that sea turtles use for nesting, the following are tenets of an effective response: (1) assess whether nests are present within the spill zone and whether nesting or hatchling emergence is ongoing or anticipated during the course of the spill or clean-up operations; (2) identify to the extent feasible any nests that are already in place and devise means to locate and mark them; (3) determine the most suitable protection measures for the situation; and (4) coordinate and communicate with any shore-based operations to ensure that personnel are aware of the presence of females, nests, or hatchlings (Fig. 1). Considerations for protecting nesting females and hatchlings include immediate evaluation of any forms of shoreline disturbance or alteration of beaches that may injure turtles or interfere with normal movements of nesting adults and emerging hatchlings. Options for protection of nests in situ include clearly marking them for avoidance by personnel and equipment, careful removal of surface oil by trained responders, and constant monitoring of incubating eggs so that emerging hatchlings can be protected as necessary. Excavation of eggs for incubation either within human-made incubators or protected artificial nests at alternate sites (i.e. ex situ protection) may be required if threats to natural nests cannot be effectively managed. Such interventions require consideration of the risks of embryonic mortality from handling eggs (Limpus et al. 1979), interference with imprinting on natal beaches (Caillouet et al. 2016), and energetic losses from disruption of the emergence and initial sea/ 
habitat-seeking behavior (Pilcher \& Enderby 2001, Balsalobre \& Bride 2016).

It is important not only to minimize the effects of a spill by protecting nests and hatchlings, but also to record or estimate total number of nests, document hatchling emergence success (i.e. the proportion of eggs laid that result in successful emergence of hatchlings), and evaluate embryonic development within the impacted area. These data are often collected by nest monitoring programs and can be essential for assessing losses to hatchling production due to oil exposure or response measure (Florida Department of Environmental Protection 1997, DWH NRDA Trustees 2016). Where possible, these data should be augmented by site-specific spill characteristics and impacts.

Observations of the condition and external oil exposure of nesting females should also be recorded if feasible. Further intervention, such as capture and transport to a rehabilitation facility, is not recommended in most circumstances, as it can disrupt reproductive cycles and have other unintended risks. Such interventions are generally reserved only for impaired females that are unable return to the water on their own.

\subsection{Offshore waters (oceanic zone): post-hatchlings and surface-pelagic juveniles}

As demonstrated in previous spills, oil and marine clean-up activities can be especially harmful to small sea turtles, and effects tend to be largely unobservable to shore-based operations. Given their distance from land, the probability of oiled surface-pelagic juvenile turtles being found ashore can be minimal to non-existent. In addition, because they are too small to be seen by conventional manned aerial surveys, deployment of vessels to locate and rescue surface-pelagic juvenile turtles is required, as demonstrated during the DWH spill (DWH NRDA Trustees 2016, McDonald et al. 2017). Rescue efforts undertaken during the DWH spill were used to study the effects of oil on sea turtles and estimate the total number of turtles that died in offshore waters as a result of the spill (DWH NRDA Trustees 2016, McDonald et al. 2017). Data collected during these operations also showed that dedicated rescue operations were able to save those individuals that could be reached alive (McDonald et al. 2017, Stacy et al. 2017).

In addition to being very vulnerable to oil spills, turtles in these life stages are poorly studied globally.
Their distribution and numbers, and at-sea density within particular areas are highly variable because they are influenced by ephemeral oceanographic features and variation in hatchling output from nesting beaches (Mansfield \& Putman 2013). Moreover, in regions of the world where they originate from multiple, low-density rookeries (e.g. Pacific Islands), small, oceanic phase turtles can be widely dispersed in low densities across extremely large areas (Parker et al. 2011). It is therefore challenging to offer broadly applicable response measures for spills in the oceanic zone.

For spills in regions such as the Northwest Atlantic and Gulf of Mexico, where small turtles are known to be found in offshore areas - potentially at high densities - response considerations include deployment of vessels for search and rescue within the spill zone; use of trained wildlife observers aboard vessels deployed for clean-up operations in offshore areas (e.g. controlled burning, oil skimming); awareness that impacts to sea turtles may be especially severe during periods of hatchling emergence; and inclusion of Sargassum communities as an important habitat under threat (if present) (Fig. 1). For areas where such information is limited or unavailable, we recommend deployment of at least pilot boat-based surveys that are suitably equipped to observe small turtles within oil.

\subsection{Offshore waters (oceanic zone): large juveniles and adults}

Options for intervention for these species and life stages during an oil spill are limited by distance of the turtles from shore, animal size, dispersed distribution, and human safety risks associated with capture within spill zones. Responders are left with the important task of documenting these turtles within spill areas so that any observed effects can be recorded and opportunities for avoidance may be identified (e.g. strategic application of dispersants or other potentially harmful measures near feeding areas). As with smaller surface-pelagic stage turtles, response personnel involved with any offshore operations should be aware of the presence of these species and how to report sightings and other observations. Key information to document for assessment of harm to oceanic species includes turtle sightings within a spill area, proximity of turtles to oil, character of the oil encountered (e.g. sheen, light or heavy slicks), and observations of dead, debilitated, or visibly oiled turtles. Dead or debilitated oiled individuals 
should be recovered for necropsy whenever possible to further document oil exposure and ascertain any associated effects.

\subsection{Nearshore-shelf waters (neritic zone): large juveniles and adults}

Sea turtles can occur in relatively high densities associated with productive foraging areas or near nesting locations during periods of reproduction, placing numbers of turtles at risk should a spill occur in these areas. As nearshore spills are likely to result in at least some live oiled turtles requiring care, identification of facilities or construction of appropriate temporary facilities for decontamination and treatment is an important need that should be addressed early during a spill.

Although oil spills do not necessarily result in large numbers of shoreline strandings of oiled turtles, surveillance of shorelines is one of the few ways in which dead and debilitated sea turtles are detected. Oiled turtles requiring care are often discovered as stranded, incapacitated animals, and may provide insight into effects that may occur in the marine environment but which are not easily observable. Shoreline surveillance should be conducted as regularly and systematically as possible, using methods that are appropriate for the physical features of the area. If present, existing stranding response networks are often a valuable resource for meeting these needs. Shoreline clean-up operations also tend to be active within spill zones and should be engaged so that workers are aware of stranded turtles and understand what to do if one is encountered. Aerial methods for shoreline surveillance for stranding animals are another option, but should consider visibility of smaller turtles (Garrison 2015).

Notably, strandings may not be a good indicator of effects from spill effects that occur far from shore when conditions do not favor shoreward drift, or when detection of stranded animals is limited by shoreline characteristics, dispersal of carcasses, or other factors (Koch et al. 2013). Because strandings represent a subset of dead or debilitated animals, extrapolation is frequently used to estimate unobserved numbers (Piatt \& Ford 1996, DWH NRDA Trustees 2016). Probability of stranding is influenced by a number of factors that are known to vary significantly by time and area, including distance from shore, prevailing wind and currents, rates of decomposition and scavenging, shoreline characteristics, and probability of discovery (Hart et al. 2006, Koch et al. 2013, Nero et al. 2013). We recommend that these factors be accurately estimated in order to support meaningful extrapolation based on numbers of stranded sea turtles.

Depending on the size and location of the spill, both in-water and shoreline surveys may be needed to document neritic-stage sea turtles within the spill zone, evaluate potential exposure to oil, detect any effects on sea turtles, and render any assistance that is feasible (Fig. 1) (Garrison 2015). Aerial surveys, in particular, are effective for observing larger juvenile and adult turtles in neritic areas and, whenever possible, should be conducted at multiple time points over the duration of a spill. Aerial surveys can also characterize habitat features relevant to sea turtles, such as foraging areas indicated by higher turtle densities (e.g. Benson et al. 2007). In addition to recording sea turtle location, species, and estimated size, other observations that may be useful for studying exposure and potential effects include the characteristics of surface oil, such as spatial extent and thickness.

Vessel-based surveys provide additional details that may not be visible to aircraft and afford the opportunity to recover floating dead or live, debilitated animals. However, directed capture of oiled neritic phase juvenile and adult turtles poses a number of logistical challenges and may be impractical under many circumstances. Larger juvenile and adult turtles are not typically concentrated like surface-pelagic juveniles, and they spend $80-90 \%$ of their time submerged (Bolten 2003), thus limiting efficiency of capture efforts. Also, human health risks in a spill zone prevent use of many standard sea turtle capture methods (e.g. entanglement nets). Other vessels deployed during an oil spill, such as those collecting oil or supporting various operations, should be made aware of the potential presence of sea turtles and other marine animals of concern and have the means to document and report oiled animals, ideally by a dedicated, on-board wildlife observer.

Considering the importance of nearshore areas to sea turtles, suggested response actions include regular communication with clean-up operations working in these areas and, where possible, dedicated surveys to document sea turtle presence and to detect dead and debilitated animals. This information should be provided to appropriate wildlife responders or organizations to provide any necessary action. Where identified, areas of persistently high-use by neritic-stage turtles (i.e. foraging areas, internesting areas adjacent to nesting beaches) may be prioritized for focused monitoring efforts. 


\section{RECOMMENDATIONS AND CONCLUSIONS}

Based on our review, and recognizing that availability of resources and expertise vary widely around the world, we provide the following general (best case) recommendations for resource managers, wildlife researchers, and other stakeholders concerned with sea turtle conservation.

- Foster an understanding of spill effects and sea turtle protections among government agencies, NGOs, academic researchers, and others of any laws, regulations, policies, or other official directives that govern spill response and assessment within their country and neighboring regions.

- As part of spill response preparedness, create an atmosphere of knowledge and communication among all response personnel to promote awareness of (1) the presence of sea turtles and their vulnerability to spills and response activities, (2) the need for sea turtles to be reported, and (3) the importance of collecting information necessary to evaluate spill effects.

- Collect, maintain, and share baseline biological information such as distribution, conservation status, abundance, habitat use, and other biological information about sea turtle species and populations present within a spill area so that this information is accessible for oil spill planning, response, and assessment purposes (Bjorndal et al. 2011). Publicly available sources of global or regional information on the presence and relative abundance of sea turtle species include Ocean Biogeographic Information System Spatial Ecological Analysis of Megavertebrate Populations (OBIS-SEAMAP; http:// seamap.env.duke.edu), SWOT (http://seamap.env. duke.edu/swot), the Wider Caribbean Sea Turtle Network (WIDECAST; http://widecast.org), and the Indian Ocean-Southeast Asia Sea Turtle Memorandum of Understanding (IOSEA; www.cms.int/ioseaturtles/en).

- Increase efforts to document sea turtles during oil spills, particularly during large spills that occur in areas of known importance to local sea turtle populations. Ideally, this would involve deploying prioritized resources for planning and implementation of response activities, surveys, and data analyses that adequately account for sea turtle biology and life history considerations.

- In order to improve the quality and consistency of data collected about spill effects on sea turtles, incorporate the following whenever practicable: - Conduct surveys of the spill area in a manner that is appropriate for the life stages found within the location under threat. Use standard field research methodology for collecting data (e.g. effort documentation, line-transect surveys) to allow for statistical extrapolation. At minimum, collect the following information:

- For oiled sea turtles, record the species, size, visible extent of oiling, and any observed or suspected resulting impairment;

- For oil spills on nesting beaches, record the numbers of nests, the extent and characteristics of oil exposure, hatchling emergence success, and any losses resulting from response actions. - Document clinical and pathological observations in affected sea turtles through evaluation by veterinarians and biologists with sea turtle expertise.

- Conduct additional studies or data analyses necessary to comprehensively estimate exposures and mortality of turtles for the entire spill area and duration. Examples of such approaches include: o Application of systematic line transect methods to shoreline, vessel, and aerial survey and animal rescue efforts to facilitate quantification and statistical expansion (Garrison 2015, McDonald et al. 2017);

o Use of remotely sensed surface oil data (e.g. synthetic aperture radar [SAR]; Garcia-Pineda et al. 2009) to estimate the spatio-temporal extent of surface oil relative to turtle locations and densities (Wallace et al. 2017b), and;

o Exploration of novel or emerging, cost-effective technologies such as unmanned aerial vehicles (UAVs; i.e. motorized drones, kites, balloons), equipped with digital cameras and other sensors for detection of sea turtles and oil (Leifer et al. 2012, Sykora-Bodie et al. 2017, Rees et al. 2018).

We offer these recommendations in an effort to ensure that sea turtles are more frequently considered in oil spill responses, spill-related data collection, and assessment of spill effects. These measures would help rectify the current dearth of available information and inform estimates of sea turtle losses. In addition, assessments should move beyond simple tallies of the numbers of turtle losses to quantification of cumulative effects on turtle populations (Wallace et al. 2008, Bolten et al. 2011). Such an approach would be useful to aid protected species managers accustomed to monitoring conservation efforts based on the magnitude of threats to population dynamics. Finally, we urge researchers and resource managers to develop plans and protocols for sea turtles and other long-lived, widely distributed marine species to guide response operations and assessments of effects when - not if — the next spill occurs. 
Acknowledgements. We acknowledge the significant efforts of responders to oil spills around the world who work on the front lines of emergency situations with potentially dire consequences for human life and property as well as natural resources. We also acknowledge several sources of information on oil spills around the world, especially those outside the USA, such as ITOPF and CEDRE. We thank B. Schroeder and T. Brosnan for insights on spill response and assessments, and M. Rissing and D. Theobald for assistance with compiling spatial information. Funding for the manuscript was provided by NOAA's Emergency Response Division and Assessment and Restoration Division through Abt Associates.

\section{LITERATURE CITED}

Al-Amirah AS (1985) The Norwuz oil spill in the Arabian Gulf: case study of Saudi Arabia. Geogr Bull 27:16-32

Balsalobre CM, Bride I (2016) Assessing the impacts of hatcheries on green turtle hatchlings. Mar Turtle Newsl 151:16-21

Bell B, Spotila JR, Congdon J (2006) High incidence of deformity in aquatic turtles in the John Heinz National Wildlife Refuge. Environ Pollut 142:457-465

Benson SR, Forney KA, Harvey JT, Carretta JV, Dutton PH (2007) Abundance, distribution, and habitat of leatherback turtles (Dermochelys coriacea) off California, 19902003. Fish Bull 105:337-347

* Beyer J, Trannum HC, Bakke T, Hodson PV, Collier TK (2016) Environmental effects of the Deepwater Horizon oil spill: a review. Mar Pollut Bull 110:28-51

Bjorndal KA, Bowen BW, Chaloupka M, Crowder LB and others (2011) Better science needed for restoration in the Gulf of Mexico. Science 331:537-538

Bolten AB (2003) Variation in sea turtle life history patterns: neritic vs. oceanic life history stages. In: Lutz PL, Musick JA, Wyneken J (eds) The biology of sea turtles, Vol 2. CRC Press, Boca Raton, FL, p 243-258

Bolten AB, Crowder LB, Dodd MG, MacPherson SL and others (2011) Quantifying multiple threats to endangered species: an example from loggerhead sea turtles. Front Ecol Environ 9:295-301

Caillouet CW, Putman NF, Shaver DJ, Valverde RA and others (2016) A call for evaluation of the contribution made by rescue, resuscitation, rehabilitation, and release translocations to Kemp's ridley sea turtle (Lepidochelys kempii) population recovery. Herpetol Conserv Biol 11: 486-496

* Camacho M, Boada LD, Oros J, Calabuig P, Zumbado M, Luzardo OP (2012) Comparative study of polycyclic aromatic hydrocarbons (PAHs) in plasma of eastern Atlantic juvenile and adult nesting loggerhead sea turtles (Caretta caretta). Mar Pollut Bull 64:1974-1980

Camacho M, Calabuig P, Luzardo OP, Boada LD, Zumbado M, Orós J (2013) Crude oil as a stranding cause among loggerhead sea turtles (Caretta caretta) in the Canary Islands, Spain (1998-2011). J Wildl Dis 49:637-640

DWH NRDA Trustees (Deepwater Horizon Natural Resource Damage Association) (2016) Deepwater Horizon oil spill programmatic damage assessment and restoration plan and programmatic environmental impact statement. Deepwater Horizon Natural Resource Damage Assessment Trustees. www.gulfspillrestoration.noaa.gov/ restoration-planning/gulf-plan/ (accessed 10 August 2017)
Eckert KL, Honebrink TD (1992) WIDECAST sea turtle recovery action plan for St. Kitts and Nevis. CEP Tech Rep No. 17. UNEP Caribbean Environment Programme, Kingston

Finlayson KA, Leusch FDL, van de Merwe JP (2016) The current state and future directions of marine turtle toxicology research. Environ Int 94:113-123

Florida Department of Environmental Protection (1997) Damage assessment and restoration plan/environmental assessment for the August 10, 1993, Tampa Bay oil spill, Vol 1: ecological injuries. NOAA Restoration Center Southeast Region, St. Petersburg, FL, p 47-51

Florida Department of Environmental Protection (2002) Final damage assessment and restoration plan/environmental impact statement for the Fort Lauderdale mystery spill. NOAA Restoration Center Southeast Region, St. Petersburg, FL

Frazier JG (2009) A turtle's tale: flagships and instruments for marine research, education, and conservation. Smithson Contrib Mar Sci 38:241-246

Fritts TH, McGehee MA (1982) Effects of petroleum on the development and survival of marine turtle embryos. Fish and Wildlife Service, US Department of the Interior, Washington, DC

* Garcia-Pineda O, Zimmer B, Howard M, Pichel W, Li X, MacDonald I (2009) Using SAR images to delineate ocean slicks with a texture-classifying neural network algorithm (TCNNA). Can J Rem Sens 35:411-421

Garrison L (2015) Estimated lethal and sub-lethal injuries of sea turtles on the continental shelf in the northern Gulf of Mexico based on aerial survey abundance estimates and surface oiling. DWH Sea Turtles Technical Working Group Report. https://pub-dwhdatadiver.orr.noaa.gov/ dwh-ar-documents/894/DWH-AR0149505.pdf (accessed 9 Jan 2020)

Gitschlag G (1991) Effects of the Mega Borg oil spill on sea turtles along the upper Texas coast. NOAA Damage Assessment Center, Rockville, MD

Greenpeace (1992) The environmental legacy of the Gulf War. Greenpeace International, Amsterdam

* Hall RJ, Bellisle AA, Sileo L (1983) Residues of petroleum hydrocarbons in tissues of sea turtles exposed to the Ixtoc I oil spill. J Wildl Dis 19:106-109

Hamman M, Fuentes MMPB, Ban NC, Mocellin VCJ (2013) Climate change and marine turtles. In: Wyneken J, Musick JA, Lohmann KJ (eds) The biology of sea turtles, Vol 3. CRC Press, Boca Raton, FL, p 353-378

* Harms CA, McClellan-Green P, Godfrey MH, Christianen EF, Broadhurst HJ, Godard-Codding C (2014) Clinical pathology effects of crude oil and dispersant on hatchling loggerhead sea turtles (Caretta caretta). In: Proc $45^{\text {th }}$ Annu Meet Int Assoc Aquatic Animal Medicine, 17-22 May 2014, Gold Coast. www.vin.com/apputil/content/ defaultadv1.aspx?pId=11397\&meta=Generic \&id=6251903 (accessed 9 Jan 2020)

* Hart KM, Mooreside P, Crowder LB (2006) Interpreting the spatio-temporal patterns of sea turtle strandings: going with the flow. Biol Cons 129: 283-290

IPIECA-IOGP (International Petroleum Industry Environmental Conservation Association-International Association of Oil and Gas Producers) (2014) Wildlife response preparedness: good practice guidelines for incident management and emergency response personnel. Report 516. IOGP, London. www.oilspillresponseproject. org/wp-content/uploads/2017/01/Wildlife_response_ 2017.pdf (accessed 9 Jan 2020) 
IPIECA-IOGP (2015) Economic assessment and compensation for marine oil releases: good practice guidelines for incident management and emergency response personnel. Report 524. IOGP, London. www.ipieca. org/resources/good-practice/economic-assessment-and -compensation-for-marine-oil-releases/ (accessed 9 Jan 2020)

ITOPF (International Tanker Owners Pollution Federation) (2005) Ocean Orbit Newsletter, October 2005. The International Tanker Owners Pollution Federation, London

ITOPF (2017) Oil spill statistics 2016. The International Tanker Owners Pollution Federation, London

Jeansonne J, Moore T, Bernhart D, Snover M (2005) Conducting a natural resource damage assessment (NRDA) for sea turtle injury from an oil spill near Ft Lauderdale, FL. In: International Oil Spill Conference Proceedings. IOSC, Washington, DC, p 95-99

Koch V, Peckham SH, Mancini A, Eguchi T (2013) Estimating at-sea mortality of marine turtles from stranding frequencies and drifter experiments. PLOS ONE 8:e56776

Kot CY, Fujioka E, DiMatteo AD, Wallace BP and others (2015) The state of the world's sea turtles online database: data provided by the SWOT team and hosted on OBIS-SEAMAP. Oceanic Society, Conservation International, IUCN Marine Turtle Specialist Group (MTSG), and Marine Geospatial Ecology Lab, Duke University. http://seamap.env.duke.edu/swot (accessed 9 Jan 2020)

K Lauritsen AM, Dixon PM, Cacela D, Brost B and others (2017) Impact of the Deepwater Horizon oil spill on loggerhead turtle Caretta caretta nest densities in northwest Florida. Endang Species Res 33:83-93

Leifer I, Lehr WJ, Simecek-Beatty D, Bradley E and others (2012) State of the art satellite and airborne marine oil spill remote sensing: application to the BP Deepwater Horizon oil spill. Remote Sens Environ 124:185-209

Leighton FA (1993) The toxicity of petroleum oils to birds. Environ Rev 1:92-103

Limpus CJ, Baker V, Miller JD (1979) Movement induced mortality of loggerhead eggs. Herpetologica 35:335-338

Lougheed LW, Edgar GJ, Snell HL (2002) Biological impacts of the Jessica oil spill on the Galápagos environment: final report v.1.10. Charles Darwin Foundation, Puerto Ayora

*utcavage ME, Lutz PL, Bossart GD, Hudson DM (1995) Physiological and clinicopathological effects of crude oil on loggerhead sea turtles. Arch Environ Contam Toxicol 28:417-422

Lutcavage ME, Plotkin P, Witherington BE, Lutz PL (1997) Human impacts on sea turtle survival. In: Lutz PL, Musick JA (eds) Biology of sea turtles. CRC Press, Boca Raton, FL, p 387-409

Mansfield KL, Putman NF (2013) Oceanic habits and habitats: Caretta caretta. In: Wyneken J, Lohmann KJ, Musick JA (eds) The biology of sea turtles, Vol 3. CRC Press, Boca Raton, FL, p 189-210

Marcondes ACJ (2015) Estratégias de proteção das áreas reprodutivas de tartarugas marinhas em casos de vazamento de óleo na costa brasileira. Trabalho de Conclusão de curso de pós graduação em Engenharia de Campo Segurança, Meio Ambiente e Saúde. MSc thesis, Universidade Federal do Espírito Santo, Vitória

Maribus (2014) World ocean review, Vol 3. Marine resources-opportunities and risks. Maribus, Hamburg

Marshall R, Bucklow R (2014) Western Australian oiled wildlife response plan. Department of Parks and Wildlife and Australian Marine Oil Spill Centre. https://www. dpaw.wa.gov.au/images/documents/conservation-man agement/marine/wildlife/West_Australian_Oiled_Wild life_Response_Plan_V1.1.pdf (accessed 9 Jan 2020)

McDonald TL, Schroeder BA, Stacy BA, Wallace BP and others (2017) Density and exposure of surface-pelagic juvenile sea turtles to Deepwater Horizon oil. Endang Species Res 33:69-82

Michel J, Fegley S, Dahlin J (2015) Deepwater Horizon Sandy Beach injury assessment. Tech Rep DWH-AR010 4418. https://www.fws.gov/doiddata/dwh-ar-documents/ 894/DWH-AR0104418.pdf (accessed 9 Jan 2020)

Mignucci-Giannoni AA (1999) Assessment and rehabilitation of wildlife affected by an oil spill in Puerto Rico. Environ Pollut 104:323-333

Miller JD (1989) Marine turtles. An assessment of the conservation status of marine turtles in the Kingdom of Saudi Arabia, Vol 1. MEPA Coastal and Marine Management Series Technical Report No. 9 Meteorology and Environmental Protection Administration, Ministry of Defense and Aviation, Jeddah

Miller JD (1997) Reproduction in sea turtles. In: Lutz PL, Musick JA (eds) The biology of sea turtles, Vol 1. CRC Press, Boca Raton, FL, p 51-79

Miller JD, Limpus CJ, Ross JP (1989) Recommendations for the conservation of marine turtles in Saudi Arabia, Vol 2. MEPA Coastal and Marine Management Series Technical Report No. 9. Meteorology and Environmental Protection Administration, Ministry of Defense and Aviation, Jeddah

Mitchelmore CL, Rowe CL (2015) Examining the effects of ingested Deepwater Horizon oil on juvenile red-eared sliders (Trachemys scripta elegans) and common snapping turtles (Chelydra serpentina) as surrogate species for sea turtles. NOAA Tech Rep DWH-AR0155280. https:// www.fws.gov/doiddata/dwh-ar-documents/894/DWHAR0155176.pdf (accessed 9 Jan 2020)

Mitchelmore CL, Bishop CA, Collier TK (2017) Toxicological estimation of mortality of oceanic sea turtles oiled during the Deepwater Horizon oil spill. Endang Species Res 33: $39-50$

* Munilla I, Arcos JM, Oro D, Álvarez D, Leyenda PM, Velando A (2011) Mass mortality of seabirds in the aftermath of the Prestige oil spill. Ecosphere 2:art83

Musick JA, Limpus CJ (1997) Habitat utilization and migration in juvenile sea turtles. In: Lutz PL, Musick JA (eds) The biology of sea turtles, Vol 1. CRC Press, Boca Raton, FL, p 137-164

NMFS (National Marine Fisheries Service) USFWS (US Fish and Wildlife Service), SEMARNAT (2011) Bi-national recovery plan for the Kemp's ridley sea turtle (Lepidochelys kempii), $2^{\text {nd }}$ revision. NMFS, Silver Spring, MD

NOAA (1992) Oil spill case histories: 1967-1991. Summaries of significant US and international spills. Rep No. HMRAD 92-11. National Oceanic and Atmospheric Administration, Seattle, WA

Nelms SE, Duncan EM, Broderick AC, Galloway TS and others (2016) Plastic and marine turtles: a review and call for research. ICES J Mar Sci 73:165-181

*Nero RW, Cook M, Coleman AT, Solangi M, Hardy R (2013) Using an ocean model to predict likely drift tracks of sea turtle carcasses in the north central Gulf of Mexico. Endang Species Res 21:191-203

NRC (National Research Council Committee on Understanding Oil Spill Dispersants) (2005) Oil spill disper- 
sants: efficacy and effects. National Academies Press, Washington, DC

Parker DM, Dutton PH, Balazs GH (2011) Oceanic diet and distribution of haplotypes for the green turtle, Chelonia mydas, in the Central North Pacific. Pac Sci 65:419-431

Peterson CH, Rice SD, Short JW, Esler D, Bodkin JL, Ballachey BE, Irons DB (2003) Long-term ecosystem response to the Exxon Valdez oil spill. Science 302:2082-2086

Petrae G (1995) Barge Morris J. Berman spill: NOAA's scientific response. HAZMAT Report No. 95-10. Hazardous Materials Response and Assessment Division, NOAA, Seattle, WA

Phillott AD, Parmenter J (2001) Influence of diminished respiratory surface area on survival of sea turtle embryos. J Exp Zool 289:317-321

Piatt JF, Ford RG (1996) How many seabirds were killed by the Exxon Valdez oil spill? In: Rice SD, Spies RB, Wolfe DA, Wright BA (eds) Proc Exxon Valdez Oil Spill Symp, 2-5 February 1993, Anchorage, AK. American Fisheries Society, Bethesda, MD, p 712-719

Pilcher NJ (2000) The green turtle, Chelonia mydas, in the Saudi Arabian gulf. Chelonian Conserv Biol 3:730-734

Pilcher N, Enderby S (2001) Effects of prolonged retention in hatcheries on green turtle (Chelonia mydas) hatchling swimming speed and survival. J Herpetol 35:633-638

Plotkin P (2003) Adult migrations and habitat use. In: Lutz PL, Musick JA, Wyneken J (eds) The biology of sea turtles, Vol 2. CRC Press, Boca Raton, FL, p 225-241

Provancha JA, Mukherjee P (2011) Late-term nest incubation and hatchling release of northeastern Gulf sea turtle nests in response to April 2010 Deepwater Horizon oil spill. DWH Sea Turtles NRDA Technical Working Group Report, Jacksonville, FL

Rabalais SC, Rabalais NN (1980) The occurrence of sea turtles on the south Texas coast. Contrib Mar Sci 23:123-129

Rees AF, Avens L, Ballorain K, Bevan E and others (2018) The potential of unmanned aerial systems for sea turtle research and conservation: a review and future directions. Endang Species Res 35:81-100

* Rowe CL, Mitchelmore CL, Baker JE (2009) Lack of biological effects of water accommodated fractions of chemically- and physically-dispersed oil on molecular, physiological, and behavioral traits of juvenile snapping turtles following embryonic exposure. Sci Total Environ 407: 5344-5355

Rützler K, Sterrer W (1970) Oil pollution damage observed in tropical communities along the Atlantic seaboard of Panama. Bioscience 20:222-224

Schwacke LH, Smith CR, Townsend FI, Wells RS and others (2014) Health of common bottlenose dolphins (Tursiops truncatus) in Barataria Bay, Louisiana, following the Deepwater Horizon oil spill. Environ Sci Technol 48: 93-103

SEMARNAT (Secretaría del Medio Ambiente y Recursos Naturales) (2012) Guía para Elaborar el Análisis de Beneficio Ambiental Neto, como Herramienta para Elegir la Mejor Respuesta en la Atención de un Derrame de Hidrocarburos en el Mar. https://backend.aprende.edu. $\mathrm{mx} / \mathrm{media} /$ uploads/tmp/resources/SMN00-2012-GU02.pdf (accessed 9 Jan 2020)

SEMARNAT (2016) Plan Nacional de Contingencia para Derrames de Hidrocarburos y Sustancias Nocivas Potencialmente Peligrosas en las Zonas Marinas Mexicanas. www.semar.gob.mx/Plan \% 20Nacional \% 20de \% 20 Contingencia\%20V2016.pdf (accessed 9 Jan 2020)
Seymour RJ, Geyer RA (1992) Fates and effects of oil spills. Annu Rev Energy Environ 17:261-283

Sforza R, Marcondes ACJ, Pizetta GT (2017) Guia de licenciamento tartarugas marinhas-Diretrizes para avaliação e mitigação de impactos de empreendimentos costeiros e marinhos. ICMBIO, Brasília

Shigenaka G (2003) Oils and sea turtle: biology, planning, and response. Office of Response and Restoration, NOAA Ocean Service, Seattle, WA

Short M (2011) Pacific adventurer oil spill: big birds, sea snakes and a couple of turtles. In: International Oil Spill Conference Proceedings. IOSC, Washington, DC, p abs207

Stacy B (2012) Summary of findings for sea turtles documented by directed captures, stranding response, and incidental captures under response operations during the BP DWH MC252 Oil Spill. DWH NRDA Sea Turtle Technical Working Group Report No. DWH-AR0149670

Stacy B (2015) Summary of necropsy findings for non-visibly oiled sea turtles documented by stranding response in Alabama, Louisiana, and Mississippi 2010 through 2014. DWH NRDA Sea Turtle Technical Working Group Report No. DWH-AR0149557. https://www.fws.gov/ doiddata/dwh-ar-documents/894/DWH-AR0149557.pdf (accessed 9 Jan 2020)

* Stacy NI, Field CL, Staggs L, MacLean RA and others (2017) Clinicopathological findings in sea turtles assessed during the Deepwater Horizon oil spill response. Endang Species Res 33:25-37

Stacy BA, Wallace BP, Brosnan T, Wissmann SM and others (2019) Guidelines for oil spill response and natural resource damage assessment: sea turtles. NOAA Tech Memo NMFS-OPR-61

* Steiner R (2006) Lebanon oil spill rapid assessment and response mission: final report. http://greenline.me.uk/ wp-content/uploads/2013/12/lebanon_oil_spill_rapid_ assessment_and_response_mission.pdf (accessed 9 Jan 2020)

* Sykora-Bodie ST, Bezy V, Johnston DW, Newton E, Lohmann KJ (2017) Quantifying nearshore sea turtle densities: applications of unmanned aerial systems for population assessments. Sci Rep 7:17690

*Van Meter RJ, Spotila JR, Avery HW (2006) Polycyclic aromatic hydrocarbons affect survival and development of common snapping turtle (Chelydra serpentina) embryos and hatchlings. Environ Pollut 142:466-475

Vargo S, Lutz P, Odell D, Van Vleet E, Bossart G (1986) Study of the effects of oil on marine turtles, Vol 2. Technical Report. US Department of the Interior Minerals Management Service, Vienna, VA

Wallace BP, Heppell SS, Lewison RL, Kelez S, Crowder LB (2008) Impacts of fisheries bycatch on loggerhead turtles worldwide inferred from reproductive values analyses. J Appl Ecol 45:1076-1085

Wallace BP, DiMatteo AD, Hurley BJ, Finkbeiner EM and others (2010) Regional management units for marine turtles: a novel framework for prioritizing conservation and research across multiple scales. PLOS ONE 5: e15465

* Wallace BP, DiMatteo AD, Bolten AB, Chaloupka MY and others (2011) Global conservation priorities for marine turtles. PLOS ONE 6:e24510

*Wallace BP, Brosnan T, McLamb D, Rowles T and others (2017a) Effects of the Deepwater Horizon oil spill on protected marine species. Endang Species Res 33:1-7 
Wallace BP, Stacy BA, Rissing M, Cacela D and others (2017b) Estimating sea turtle exposures to Deepwater Horizon oil. Endang Species Res 33:51-67

Watson JEM, Joseph LN, Watson AWT (2009) A rapid assessment of the impacts of the Montara oil leak on birds, cetaceans and marine reptiles. Department of the Environment, Water, Heritage and the Arts, Canberra

Whittow GC, Balazs GH (1982) Basking behavior of the Hawaiian green turtle (Chelonia mydas). Pac Sci 36:129-139

Wikelski M, Wong V, Chevalier B, Rattenborg N, Snell HL (2002) Marine iguanas die from trace oil pollution. Nature 417:607-608

Editorial responsibility: B. Louise Chilvers, Palmerston North, New Zealand
Witham R (1978) Does a problem exist relative to small sea turtles and oil spills? In: Proc Conf Assessment of ecological impacts of oil spills, 14-17 June, Keystone, CO. American Institute of Biological Science, Cambridge, MA, p 630-632

*Witherington B (2002) Ecology of neonate loggerhead turtles inhabiting lines of downwelling near a Gulf Stream front. Mar Biol 140:843-853

*Witherington B, Hirama S, Hardy R (2012) Young sea turtles of the pelagic Sargassum-dominated drift community: habitat use, population density, and threats. Mar Ecol Prog Ser 463:1-22

Submitted: April 3, 2019; Accepted: November 11, 2019

Proofs received from author(s): January 10, 2020 